\title{
A Contrastive Study of Four English Versions of Labor Contract Law of the People's Republic of China
}

\author{
Mao Zhang \\ No. 2Baiyun Dadao Bei, School of Interpreting and Translation Studies \\ Guangdong University of Foreign Studies \\ zhang1202mao@163.com
}

\begin{abstract}
Law is a system of rules of conduct that are created by the national legislature in accordance with the legislative procedures and are enforced by the state power. Legal language, as the manifestation of law and the carrier of the legal information, must be accurate and formal. On the ground of the special function of law, words are dedicatedly selected and used within the given field in legal texts. Some unique lexical features of legal language can be found easily to ensure the accuracy and formalness of legal texts, such as the employment of archaic words, the use of loan words and the application of formal words. The contrastive study is conducted from the lexical aspect of the four English versions of Labor Contract Law of the People's Republic of China, with an attempt to find out the differences in formalness of the law caused by different uses of words in four versions and wish legal translators pay more attention to formality and accuracy of legal words. As for the four versions, one is taken from PKU's legal academic sector, marked as V1 in the following comparative study. One is translated by Backer \& Mckenzie(V2), one of the biggest legal agents in the world, which functions as an introduction of Chinese government's policies concerning labor contracts to the world. One is taken from the official website the National People's Congress of the People's Republic of China (NPC), marked as V3. And the other is taken from Shuangcheng Attorneys at Law in association with China Axis Limited, marked as V4 in the following contrastive study.
\end{abstract}

Keywords: legal translation; formality; Labor Contract Law of the People's Republic of China

Academic Discipline And Sub-Disciplines: Linguistics.

SUBJECT CLASSIFICATION: Linguistics Subject Classification.

TYPE (METHOD/APPROACH: Language contrast.

Language: English

Date of Publication: 2018-07-30

DOI: $10.24297 /$ jal.v9i1.7515

ISSN: $2348-3024$

Volume: 09 Issue: 01

Journal: Journal of Advances in Linguistics.

Website: https://cirworld.com

This work is licensed under a Creative Commons Attribution 4.0 International License. 


\section{FORMAL WORDS}

According to American linguist Martin Joos (1967) the style can be divided into frozen style, formal style, consultative style, casual style and intimate style. Legal texts are regulations or truths about the obligations and rights of the parties involved in a specific legal subject field. Therefore, the style of legal texts is highly formal. In order to manifest the solemnity and authoritativeness of legal language and make it more stylistically prominent, words and expressions in legal documents and texts mainly are formal written words rather than common words. In addition to that, formal words in legal texts refer to very formal words and expressions that are less used in written style.

Example 1: 本条所称月工资是指劳动者在劳动合同解除或者终止前十二个月的平均工资。(第四十七条)

V1: The term of "monthly wage" mentioned in this Article refers to the employee's average monthly wage for the 12 months prior to the dissolution or termination of his labor contract.

V2: For the purposes of this Article, the term "monthly wage" means the Employee's average monthly wage for the 12 months prior to the termination or ending of his employment contract.

"终止" is translated into "termination" in V1, V3 and V4, while is translated into "ending" in V2. Considering the length of the paper, V3 and V4 are not listed. "end" is often used in everyday English to express the same meaning of "termination", but the former word is less formal than the latter one when it comes to legal texts. When translating legal documents, translators can never be too careful about the accuracy of words.

Example 2: 劳动报酬低于当地最低工资标准的，应当支付其差额部分。（第八十五条）

V1: If the remuneration is lower than the local minimum wage, the employer shall pay the shortfall.

V3: if the labor remuneration is lower than the local minimum wage rate, it shall pay the difference.

The use of formal words is believed to help maintain the normativity and seriousness of legal texts through the translation process. For this purpose, in legal translation, "the shortfall" is more often used than "the difference". Similarly, "before" is usually replaced by "prior to" for the formalness of translated legal texts as shown in the following Ex3.

Example 3:本法施行前已依法订立且在本法施行之日存续的劳动合同, 继续履行。（第九十七条）

V1: labor contracts concluded before the implementation of this Law and continue to exist on the implementation date of this Law shall continue to be performed.

V3: A labor contract which is concluded in accordance with law prior to implementation of this Law and remains valid as of the date this Law goes into effect shall continue to be performed.

\section{LOAN WORDS}

A loan word is a word borrowed from one language and incorporated into another. (Wikipedia, 2010) It is not uncommon that the legal language of one country is incorporated with many other languages. Common law is composed of English, Latin and French. Since the Normans conquered Britain in the $11^{\text {th }}$ century, French has been incorporated into English legal texts, adding a touch of elegance to the legal language. Since Christianity was introduced to Britain in 597AD, Latin has been commonly used in legal texts. The following chart is about Latin words, French words and English words of the same meaning. We can see that Latin words are always more complex than the words in French and English. It has been wildly recognized that the employment of Latin words can show a higher formality degree of legal texts. 
Table1: Contrast between Latin, French and English words

\begin{tabular}{|l|l|l|}
\hline Latin & French & English \\
\hline Conflagration & Flame & Fire \\
\hline Secure & Firm & Fast \\
\hline Interrogate & Question & Ask \\
\hline Conclude & Close & Shut \\
\hline Epoch & Age & Time \\
\hline Ascend & Mount & Rise \\
\hline
\end{tabular}

Similarly, Chinese civil law has absorbed a great number of features of other languages. In other words, Chinese civil law has developed in an environment full of different kinds of languages. Loan words play a significant role in the most-often used legal words of Chinese law. Take the Contract Law of the People's Republic of China promulgated in 1999 as an example. The legal provisions are dotted with loan words from English, German and Latin, such as unauthorized disposition and counterargument right for simultaneous performance. In addition to English, German and Latin, many Chinese legal terms are translated from Russian, Japanese and French. Because at the end of the 19th century, the Qing Dynasty drafted its own law according to the Japanese law which was just translated into Chinese. During the period of the national government, the Chinese version of the law of European countries dominates the creation of Chinese law at the time. From 1949 to 1980, nearly all laws of the People's Republic of China were actually translated from Soviet law. In the last two decades of the 20th century, many loan words from English can be found in Chinese law, as a large number of English law and legal books were translated into Chinese.

Example 4:用人单位招用劳动者, 不得扣押劳动者的居民身份证和其他证件, 不得要求劳动者提供担保或者以其 他名义向劳动者收取财物。(第九条)

V1: When an employer hires an employee, it shall not detain his identity card or other certificates, nor require him to provide a guaranty or collect money or property from him under any other excuse.

V2: When hiring an Employee, an Employer may not retain the Employee's resident ID card or other papers, nor may it require him to provide security or collect property from him under some other guise.

The two English versions coincide with a pretty similar translation of "担保"respectively as "guaranty" and "security". The word "guaranty" is actually a loan word borrowed from French. Normally these two words have the same meaning in legal texts. Nevertheless, the loan word chosen in V1, V3 and V4 exemplifies the emphasis on accuracy and formalness of a translated legal text.

Example 5:劳动报酬的数额, 参照本单位相同或者相近岗位劳动者的劳动报酬确定。(第二十八条)

V1: The amount of remunerations shall be determined by analogy to the remuneration to the employees taking up the same or similar positions of the employer.

V3: The amount of remuneration shall be determined mutatis mutandis according to that for the workers holding the same or similar posts in the employing unit.

"mutatis mutandis" is a Latin word, meaning with "appropriate changes when comparing cases", which has a more accurate and precise meaning than "by analogy to" in V1. This word is used when you are comparing two 
or more things or situations, it means making small changes that are necessary for each individual case, without changing the main points. From the perspective of authority and dignity of translated legal texts, V3 is, without doubt, preferred in official translation of laws and rules.

\section{ARCHAIC WORDS}

In language, an archaic word is the use of a form of speech or writing that is no longer current. Old English had been used until 1500 BC. And 70\% of archaic legal words borrowed from Latin, French and Greek during that period have been used till today. Because of the Plain English Campaign, archaic words are rarely used in modern English. But they are frequently encountered in legal texts in order to demons trate the solemnity and authoritativeness of legal language. Legal minds think it is necessary to preserve archaic words in legal texts as they can make legal sentences more precise, succinct and serious. It has considered as an obvious feature of legal documents and contributed to the formalness of legal texts.

Despite of the Plain English Campaign, archaic words have every reason to be remained in legal texts and add a touch of formality to the language where they occur. All languages which are being used are facing the natural election. As history moves on, the essence will be left. And archaic words are the essence of legal language. Different from the daily communications, the legal translation plays a special role in need of accuracy and formalness archaisms could bring about. As David Crystal and D. Davy point out that it is especially noticeable that any passage of legal English is usually well stubbed with archaic words and phrases of a kind that could be used by no one but lawyers. (David Crystal \& D. Davy, 1969:208)

According to the following statistics, the version translated by Backer \& Mckenzie(V2) is highly demonstrated the distinctive feature of legal language by adopting the most archaic words. By contrast, the version taken from the official website the National People's Congress of the People's Republic of China (V3) pays insufficient attention to archaic words in translation and consequently seems less formal in its effect.

Table2: The frequency of three typical archaic words in four versions

\begin{tabular}{|c|c|c|c|c|}
\hline Versions & V1 & V2 & V3 & V4 \\
\hline Thereof & 3 & 7 & 0 & 3 \\
\hline Hereof & 2 & 30 & 0 & 23 \\
\hline Pursuant to & 1 & 15 & 0 & 0 \\
\hline
\end{tabular}

The following examples are listed to show the pleasant effect due to the employment of archaic words in the four English versions of Labor Contract Law of the People's Republic of China.

Example 6:劳动合同期满, 有本法第四十二条规定情形之一的, 劳动合同应当续延至相应的情形消失时终止。 (第四十五条)

V1: If a labor contract expires and it is under any of the circumstances as described in Article 42 of this Law, the term of labor contract shall be extended until the disappearance of the relevant circumstance. 
V2: If an employment contract expires and any of the circumstances specified in Article 42 hereof applies, the term of the employment contract shall be extended until the relevant circumstance ceases to exist, at which point the contract shall end.

"本法" is translated into "of this law" in V1, V3 and V4, while into "hereof" in V2. Considering the length of this paper, V3 and V4 are not listed. The four versions are all acceptable, but the employment of archaic word "hereof" in V2 can make readers read an original legal document in English rather than one which is translated into Chinese, as it is now only used in special English varieties, such as legal documents.

Example 7:（一）用人单位制定直接涉及劳动者切身利益的规章制度及其执行的情况。(第七十四条)

V1: 1. The employers' formulation of rules and regulations directly related to the interests of workers, and the implementation thereof.

V3: (1) the rules and regulations formulated by the employing units that have a direct bearing on the immediate interests of the workers, and the implementation of such rules and regulations.

In the above example, "及其" is translated into "thereof" in V1, V2 and V4, while is translated into "of such rules and regulations" in V3. The translation is more formal by employing the word of "thereof", though words "of such rules and regulations" in V3 are of the same meaning. Therefore, the adoption of archaic words adds to the formalness of the version as they manifest the prominent feature of legal English.

Example 8: 本法施行之日存续的劳动合同在本法施行后解除或者终止, 依照本法第四十六条规定应当支付经济 补偿的, 经济补偿年限自本法施行之日起计算。(第九十七条)

V1: If a labor contract existing on the implementation date of this Law is dissolved or terminated after the implementation of this Law and, according to Article 46 of this Law, an economic compensation is payable, the number of years for which the economic compensation is payable shall be counted from the implementation date of this Law.

V3: Where a labor contract which remains valid as of the date this Law goes into effect is revoked or terminated thereafter financial compensation shall be paid pursuant to the provisions of Article 46 of this Law, and the number of years for which financial compensation should be paid shall be calculated from the date this Law goes into effect.

“在本法施行后" is translated into "after the implementation of this Law" in V1, V2 and V4, while is translated into "thereafter" in V3. In this example, with the expression of "thereafter", V3 is more formal than the other three English versions. The accuracy, formalness and even the conciseness brought from the use of the archaic words can be clearly demonstrated.

\section{TERMS OF ART}

A term of art refers to a technical word with a specific meaning in a certain register of language, which does not necessarily refer to art or technology. Legal technical terms, often called (legal) terms of art or (legal) words of art, have meanings that are strictly defined by law. (Wikipedia,2010) Terms of art abound in the law. For example, the phrase double jeopardy can be used in common parlance to describe any situation that poses two risks. In the law, double jeopardy refers to specifically to an impermissible second trial of a defendant for the same offense that gave rise to the first trial.

Generally speaking, terms of art are formally recognized and documented, evolving due to the need for experts in a field to communicate with precision and brevity. But they often have the effect of excluding those who are unfamiliar with the particular specialized language of the group at the same time. Take legal English 
as an example. The used of terms of art is usually regarded as a necessary sacrifice to guarantee the solemnity and authority of the law.

Because of communication of legal cultures and law migration, translation of legal terms is in a mess. At the macroscopic level, this situation is attributed to lack of attention and slow improvement. That we do not effectively inherit the achievements made by pioneers also contributes to the situation. At the microscopic level, the current translation of legal terms is not professional and systematic enough. (Qu states) Some of these problems are showed in the following examples in the four versions of Labor Contract Law of the People's Republic of China.

Example 9: 劳动者违反服务期约定的, 应当按照约定向用人单位支付违约金。(第二十二条)

V1: If an employee violates the stipulation regarding the service time period, he shall pay the employer a penalty for breach of contract.

V2: If the Employee breaches the agreement on the term of service, he shall pay liquidated damages to the Employer as agreed.

V3: If the worker breaches the agreement on the term of service, he shall pay a penalty to the employing unit as agreed upon.

V4: If the worker breaches the agreement on term of service, he/she shall pay liquidated damages to the Employer as agreed.

According to Black's Law Dictionary (eighth edition), "penalty" refers to an extra charge against a party who violates a contractual provision. Penalty clause. A contractual provision that assesses against a defaulting party an excessive monetary charge unrelated to actual harm. Penalty clauses are generally unenforceable. And "liquidated damages" refers to an amount contractually stipulated as a reasonable estimation of actual damages to be recovered by one party if the other party breaches. If the parties to a contract have properly agreed on liquidated damages, the sum fixed is the measure of damages for a breach, whether it exceeds or falls short of the actual damages. Where the terms of a contract specify a sum payable for non-performance, it is a question of construction whether the sum is to be treated as a penalty or as liquidated damages. The difference in effect is this: The amount recoverable in case of a penalty is not the sum named, but the damages actually incurred. The amount recoverable as liquidated damages is the sum named as such. In construing these terms a judge will not accept the phraseology of the parties; they may call the sum specified 'liquidated damages,' but if the judge finds it to be a penalty, he will treat as such." We can tell from above that "penalty" and "liquidated damages" have different legal meanings. The former one refers to damages that are much larger than the actual loss resulted from breaching of contract. The latter ones, which are usually fixed in advance, refer to reasonably predicted damages of the actual loss.

In the LCLPRC, the amount of money that the employer should pay for the employee when he/she breaches the agreement on the term of service is fixed in advance. And the employer and the employee are not mean to make the article in the contract unenforceable. Hence translators should avoid applying the legal term of "penalty". As for the four English versions, V2 and V4 are clearly more accurate and precise than V1 and V3.

Although there are some same uses of terms or jargons in the four translated versions, most of which have had a prevailing application and been well acknowledged in legal translation, there is a gap in the proper use of the technical terms. As a whole, the use of terms of art in V2 and V4 appears to be more appropriate than that in V1 and V3.

\section{CONCLUSION}

In this paper, the translation of legal texts has been discussed in the lexical aspect, attempting to reveal the importance of applying the accurate words in legal translation and the influence of these words on the formality degree of the legal text by taking as examples the four English versions of Labor Contract Law of the People's Republic of China. This paper has demonstrated that law is characterized as formal and serious, and accordingly the legal language must be accurate and formal. This special feature contained in legal language 
decides the unusual difficulties in legal translation. Translators of legal texts are burdened with heavy responsibilities and must pay much attention to the accuracy of words, such as the employment of archaic words and loan words, replacing common words with formal words and the accuracy of the terms of art.

Through the analysis and contrast, it can be concluded that in terms of formal words, there is no apparent difference in the four versions. In terms of loan words, the third version taken from the official website the National People's Congress of the People's Republic of China (NPC) is better than the other three versions. With a large number of archaic words, the second version translated by the legal agent Backer \& Mckenzie is the most formal one in four versions with respect to the employment of archaic words. The terms of art in the second version and the fourth version taken from Shuangcheng Attorneys at Law in association with China Axis Limited are translated more accurately and precisely, comparing to the first and the third versions. Hence the former two versions seem to be more formal and serious.

Owing to the limitation of author's professional knowledge and the lack of practice in legal translation, this paper is far from the completely satisfactory and is only presented as a tentative exploration in legal translation. With the economic development and the deepening of China's reform and opening up to the outside world, China has inevitably taken part in keener interactions with foreign countries in fields like trading, touring and high-tech energy. In this context, much more importance has been attached to the translation of legal texts which plays an important role in economic and cultural exchanges conducted between China and other countries. It is hoped that the translation of legal texts will be more accurate and formal.

\section{ACKNOWLEDGEMENTS}

I would like to express my gratitude to Professor Zhao Junfeng, the dean of the School of Interpreting and Translation Studies of Guangdong University of Foreign Studies. I determined the theme of the paper and searched for related materials with the help of Professor Zhao, who is very busy yet patient. I also gratefully acknowledge the help of my supervisor, Professor Zhu Wenzhong, who has offered me valuable suggestions during the writing of the paper. Without their patient instruction and expert guidance, I would not have completed the paper.

At last, I would like to extend my sincere gratitude to my parents and my sister for their continuous support and encouragement.

\section{REFERENCES}

[1] Bryan A. Garner. Black's Law Dictionary [M]. Minnesota: West Publishing Company, 1999.

[2] Baker \& Mckenzie. Law of the People's Republic of China on Employment Contracts, 2008-1-1.

[3] David Crystal \& D. Davy. Investigating English style [M]. London: Longman group Ltd, 1969:208.

[4] Dong Bao Hua \& Russell. A, Labor Contract Law of the People's Republic of China, http://digitalcommons.ilr.cornell.edu/cgi/viewco ntent.cgi?article=1026\&context=

intl, 2010-05-26.

[5] Gibbons, J. 1994. Language and the Law. New York: Longman Group UK Limited.

[6] MacLeish, A.\& David, M. Review of The Language of the Law[J]. Harvard Law Review,1964:490-491. 
[7] NPC, Labor Contract Law of the People's Republic of China, http://www.mohrss.gov.cn/SYrlzyhs hbzb/zcfg/flfg/fl/201605/t20160509_239643.html, 2009-5-25.

[8] Sir William Reynell Anson. Principles of the Law of Contract [M]. America: Nabu Press, 2010:470.

[9] Susan Sarcevic. New Approaches to Lega Translation[M]. London: Kluwer Law International, 1997.

[10] Standing Committee of the National People's Congress. Labor Contract Law of the People's Republic of China. 12-28-2012.

[11] You Xueyun, Improve Labor Contract System, Safeguard Lawful Rights and Interests of Laborers-An interview with Prof. Guan Huai of Law School of Renmin University of China[J]. Human Rights, 2006,05 : 912.

[12] Wikipedia, "Loan Word", http://en.wikipedia.org/wiki/Loan_word, 2017-1-15.

[13] Wikipedia, "Terms of Art", http://en.wikipedia.org/wiki/Terms_of_art, 2017-1-15.

[14]杜金榜.《法律语言学》[M].上海：上海外语教育出版社，2004.

[15]胡伟君. 中华人民共和国合同法两译本的比较研究[D].上海外国语大学.2010.

[16]李青. 《中华人民共和国合同法》两种译本中的动词英译对比研究-- 以情态动词与动词误译为例 [D]. 辽宁: 大 连海事大学, 2010.

[17]刘雪丹.论《中华人民共和国合同法》的翻译[D].上海：上海海事大学， 2007.

[18]阮雯超. 目的论关照下的法律翻译一兼析《中华人民共和国劳动合同法》英译[D].上海：上海外国语大学， 2010: 28-35.

[19] 屈文生.法律翻译研究的视角与思路——对法律翻译若干重要方面的梳理和理性评价 [J].江西社会科学, 2010(2): 2-3.

[20]屈文生.中国法律术语对外翻译面临的问题与成因反思一一兼谈近年来我国法律术语译名规范化问题[J].中国 翻译, 2012,(6): 3-6.

[21]张法连.法律语言研究[M].济南: 山东大学出版社, 2017: 78-87.

[22]中国劳动社会保障社编.《中华人民共和国劳动合同法》[Z].北京：中国劳动社会保障出版社， 2007.

\section{Author' biography with Photo}

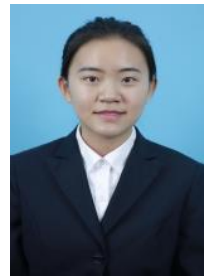

Mao Zhang, a post-graduate student who major in English-Chinese translation and interpreting, especially the legal translation, of Guangdong University of Foreign Studies. Mao Zhang has already passed the China Accreditation Test for Translators and Interpreters Level 2. Now Mao Zhang is a member of the translation team of Guangdong University of Foreign Studies, focusing on the translation of news on the Chinese Foreign Ministry website and the Confucius Institute Headquarters (Hanban) website. 